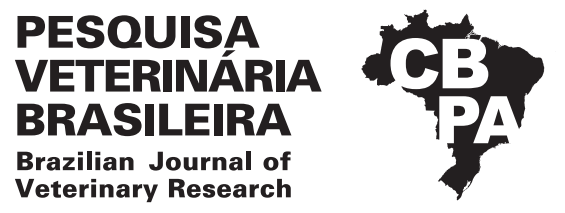

Pesq. Vet. Bras. 38(9):1736-1741, setembro 2018 DOI: 10.1590/1678-5150-PVB-5663

Original Article

Animais de Produção/Livestock Diseases

ISSN 0100-736X (Print)

ISSN 1678-5150 (Online)

\title{
Detection of Listeria spp. in cattle and environment of pasture-based dairy farms ${ }^{1}$
}

\author{
Carolina Matto ${ }^{2 *}$, Gustavo Varela ${ }^{3}$, Valeria Braga ${ }^{3}$, Victoria Vico ${ }^{3}$, \\ Ruben E. Gianneechini ${ }^{2}$ and Rodolfo Rivero ${ }^{2}$
}

\begin{abstract}
Matto C., Varela G., Braga V., Vico V., Gianneechini R.E. \& Rivero R. 2018. Detection of Listeria spp. in cattle and environment of pasture-based dairy farms. Pesquisa Veterinária Brasileira 38(9):1736-1741. Laboratorio Regional Noroeste DILAVE "Miguel C. Rubino", Ministerio de Ganadería, Agricultura y Pesca, Ruta 3 Km 369, C.P. 60.000, Paysandú, Uruguay. E-mail: cmatto@mgap.gub.uy

The aim of the study was to detect Listeria spp., particularly Listeria monocytogenes, in cattle and environment of pasture based dairy farms in Paysandú, Uruguay. A two-stage sampling was conducted, 10 farms were selected by probability proportional to size. A single visit was made to each farm. Samples from bovine faeces, feedstuffs, bulk tank milk, drinking water and soil from the entry and exit pens of the milking parlour were collected for bacteriological studies. PCR assays were used to confirm species and determine the serotype profile of L. monocytogenes isolates. AscI-pulsed-field gel electrophoresis was done to genetically compare them. Listeria spp. were isolated from eight of ten dairy farms, whereas L. monocytogenes in three of them. Serotype distribution in L. monocytogenes was as follows: $1 / 2 \mathrm{a}$, three isolates; $4 \mathrm{~b}$, one isolate. L. monocytogenes or L. innocua excreted from clinically healthy milking cows was detected via faeces. In feedstuffs, only one L. monocytogenes $1 / 2 \mathrm{a}$ isolate from a pasture was obtained. The strain was identical by PFGE to an isolate $1 / 2 \mathrm{a}$ obtained from a pool of milking cow feces that grazed on this farm. No isolation of Listeria spp. was retrieved from the bulk tank milk or drinking water from any of the farms. Listeria innocua was detected in 13 feedstuffs and seven samples of soil from the entry and exit pens of the milking parlour. This is a first local study that confirms the presence of Listeria spp. including L. monocytogenes in healthy cattle and environment of pasture-based dairy farms. These results suggest the potential role that healthy cattle and their sub-products would play as a source of these agents for humans and/or others animals. More detailed studies that include genetic comparison of human and animal isolates are required in order to clearly establish the epidemiological relationship.
\end{abstract}

INDEX TERMS: Listeria spp., cattle, dairy farms, faecal shedding, listeriosis, graze, milk, bacterioses.

\begin{abstract}
RESUMO.- [Detecção de Listeria spp. em gados leiteiros no meio ambiente com base na pastagem.] 0 objetivo deste trabalho foi detectar a presença de bactérias do gênero Listeria e particularmente Listeria monocytogenes, em bovinos leiteiros no ambiente de Paysandú, Uruguai. Foi realizada uma amostragem em duas etapas, dez estabelecimentos foram selecionados por probabilidade proporcional ao tamanho.
\end{abstract}

\footnotetext{
${ }^{1}$ Received on February 23, 2018.

Accepted for publication on March 28, 2018.

${ }^{2}$ Laboratorio Regional Noroeste DILAVE 'Miguel C. Rubino', Ministerio de Ganadería, Agricultura y Pesca, Ruta 3 Km 369, C.P. 60.000, Paysandú, Uruguay. *Corresponding author: cmatto@mgap.gub.uy

${ }^{3}$ Instituto de Higiene, Facultad de Medicina, Universidad de la República, Alfredo Navarro 3051, C.P. 11.600, Montevideo, Uruguay.
}

Foi realizada uma única visita a cada propriedade. Foram coletadas amostras para cultura bacteriológica de matéria fecal bovina, além de alimentos, leite do tanque de resfriamento, água e solo na entrada e saída da sala de ordenha. Com os isolados de L. monocytogenes foi realizado PCR para a confirmação da espécie e determinação do perfil do serotipo. AscI-elctroforese em gel de campo pulsado foi realizado para compará-los geneticamente. Listeria spp. foram isoladas de oito de dez estabelecimentos, enquanto $L$. monocytogenes foram detectadas em três deles. A distribuição dos serotipos nos isolados de L. monocytogenes recuperados foi: $1 / 2$ a três isolados, $4 \mathrm{~b}$ um isolado. Foram detectadas vacas leiteras clinicamente sadias que excretaram L. monocytogenes ou L. innocua nas fezes. Dos alimentos do gado houve só um isolamento de 
L. monocytogenes $1 / 2 \mathrm{a}$ em uma pastagem. Esta estirpe foi idêntica no PFGE a um isolado 1/2a obtido de uma "piscina" de fezes de vacas leiteiras do mesmo estabelecimento. Não houve isolamento de Listeria no leite do tanque de resfriamento ou na água de nenhum dos estabelecimentos. Listeria innocua foi detectada em 13 alimentos para o gado e sete amostras de solo na entrada e saída da sala de ordenha. Este parece ser o primeiro estudo local que confirma a presença de Listeria spp. incluindo $L$. monocytogenes em vacas leiteiras sadias e no meio ambiente de propriedades leiteiras com base alimentícia na pastagem. Esses resultados sugerem o potencial de vacas sadias e seus subprodutos como possível fonte desses agentes para humanos e/ou outros animais. São necessários estudos mais detalhados que incluem a comparação genética de isolados humanos e de animais para estabelecer claramente seu relacionamento epidemiológico.

TERMOS DE INDEXAÇÃO: Listeria spp., gados leiteiros, meio ambiente, bovinos, fezes, listeriose, pastagem, leite, bacterioses.

\section{INTRODUCTION}

The genus Listeria is composed of gram-positive saprophytic bacteria widely distributed in the environment (VázquezBoland et al. 2001, Lyautey et al. 2007b, Linke et al. 2014). Till now 17 species have been identified (Orsi \& Wiedmann 2016). Listeria monocytogenes is the species usually associated with animal and human disease, although less frequently, has been described cases due to L. ivanovii or L. innocua (Low \& Donachie 1997, Vázquez-Boland et al. 2001, Rocha et al. 2013). Contaminated dairy products are one of most common foods involved in human listeriosis outbreaks. Milk pasteurisation has reduced the risk, even though cases continue resulting from post processing contamination and consumption of raw milk products (Cartwright et al. 2013).

Ruminants are particularly susceptible to infection, being rhombencephalitis the most common clinical presentation (Oevermann et al. 2010). Cases of miscarriage, neonatal septicaemia, keratoconjunctivitis/uveitis and enteritis have also been reported (Low \& Donachie 1997, Oevermann et al. 2010, Fairley \& Colson 2013). Among ruminants, bovine species has the highest prevalence of carrier animals that shed bacteria asymptomatically (Nightingale et al. 2004, Esteban et al. 2009). This prevalence could be related to greater environmental contamination on cattle farms (Nightingale et al. 2005). The main source of L. monocytogenes infection in ruminants is poorly fermented silage (Nightingale et al. 2005, Ho et al. 2007) but there are reports of listeriosis in grazing ruminants in New Zealand and Uruguay (Fairley et al. 2012, Matto et al. 2017).
Dairy cow herds show a higher prevalence of asymptomatic carriers than beef cattle (Esteban et al. 2009, Mohammed et al. 2009a). In epidemiological studies carried out on dairy farms, L. monocytogenes has been recovered from feedstuffs, drinking water, bedding, soil, insects, troughs, milking machine, bulk tank milk, effluent and bird faeces (Nightingale et al. 2004, Latorre et al. 2009, Mohammed et al. 2009b). The main epidemiological surveys about presence of $L$. monocytogenes in dairy farms were performed in confinement systems (i.e. freestall, tiestall farms) (Esteban et al. 2009, Latorre et al. 2009, Mohammed et al. 2009b). However in Uruguay, most of dairy farms have pasture based feeding systems (INALE 2017) and there is no information available about presence of this pathogen. The objective of this work was to detect the presence of L. monocytogenes in milking cows and environment of pasture-based dairy farms in Paysandú, Uruguay.

\section{MATERIALS AND METHODS}

Design and study population. The study was a detection sampling. The sampling frame was 131 dairy farms that send milk to the industry from Paysandú County, Uruguay. The bovine population in these farms was 40.235 animals. A two stage sampling was carried out, selecting ten farms by probability proportional to size, using ProMESA 1.3 programme (León \& Duffy 2009).

Samples collected. Each farm was visited only once to collect milking cow feces, bulk tank milk, soil from the entry and exit corral of the milking parlour, water and feedstuffs consumed by these cows on the day of the visit (Table 1).

Based on reports the prevalence of cattle that shed Listeria monocytogenes asymptomatically is about $10 \%$ (Lyautey et al. 2007a, Latorre et al. 2009) fecal samples from 30 milking cows randomly selected were collected. Feces were obtained directly from the rectum of each cow, using a plastic sleeve for each sample. Then, there were transferred to sterile bags. All cows included in this study were healthy at the sampling time.

Drinking water was collected into a $500 \mathrm{~mL}$ sterile bottle from the trough nearest to the milking parlour. Five-hundred $\mathrm{mL}$ of milk was taken directly from the bulk tank with a sterile ladle and transferred to a sterile bottle. Approximately $50 \mathrm{~g}$ of soil was collected in a sterile bag from ten points of entry and exit pens of the milking parlour. A total of 39 feed samples of approximately $100 \mathrm{~g}$ each one were collected in sterile bags (Table 2). Pasture was cut in ten random points of each paddock sampled where milking cows graze. Silage and concentrate samples were taken directly from the silo. Hay sample was taken from the middle of it. All samples

Table 1. Samples obtained during visits of the ten dairy farms, quantity and percentage of isolates of the genus Listeria by specie

\begin{tabular}{lcccc}
\hline & Samples cultured & L. innocua & L. monocytogenes & Negative \\
\hline Bulk tank milk & 10 & 0 & 0 & 0 \\
Water & 10 & 0 & 0 & $10(100 \%)$ \\
Soil & 10 & $7(70 \%)$ & $3(5.2 \%)$ & $3(30 \%)$ \\
Pool of faeces & 58 & $30(51.8 \%)$ & $1(2.6 \%)$ & $25(43 \%)$ \\
Feedstuffs & 39 & $13(33.3 \%)$ & 4 & $25(64.1 \%)$ \\
TOTAL & 127 & 50 & 73
\end{tabular}


were labelled and kept refrigerated in a cooler at $4^{\circ} \mathrm{C}$ until processing in the laboratory.

Bacteriological analysis. Samples were processed immediately after receiving them according to FSIS (2017) protocol and Nightingale et al. (2004). Six pools of faces were analysed from each farm. Two-hundred and twenty-five $\mathrm{mL}$ of Listeria UVM I enrichment broth $\left(\mathrm{Oxoid}^{\circledR}\right)$ was added to $25 \mathrm{~g}$ of feces or feedstuffs. Water was filtered using a sterile $0.45 \mu \mathrm{m}$ cellulose filter (Sartorius ${ }^{\circledR}$ ) later, was transferred to a sterile bag and added $100 \mathrm{~mL}$ of Listeria UVM I enrichment broth $\left(\mathrm{Oxoid}^{\circledR}\right)$. All cultures were homogenized two minutes in a stomacher (Seward ${ }^{\circledR}$. After that, were incubated at $30^{\circ} \mathrm{C}$ for 24 hours. Then, $100 \mu \mathrm{L}$ of the culture was transferred aseptically to $10 \mathrm{~mL}$ of Listeria UVM II enrichment broth $\left(\mathrm{Oxoid}^{\circledR}\right)$ and incubated for another 24 hours at $30^{\circ} \mathrm{C}$. Then, $100 \mu \mathrm{L}$ of the culture was streaked on Modified Oxford agar plates (MOX) (Oxoid ${ }^{\circledR}$ ) and incubated at $35^{\circ} \mathrm{C}$ for 48 hours. Plates were checked at 24 and 48 hours. Milk samples were processed according to Van Kessel et al. (2004), 250 $\mathrm{LL}$ of milk was streaked in triplicate on MOX plates and incubated at $37^{\circ} \mathrm{C}$ for 48 hours; the plates were checked at 24 and 48 hours. At the same time, $10 \mathrm{~mL}$ of milk was added to $90 \mathrm{~mL}$ of Modified Listeria UVM enrichment broth (Acumedia ${ }^{\circledR}$ ) and incubated at $37^{\circ} \mathrm{C}$ for 48 hours before being re-isolated on MOX plates. On all cultures presenting the Listeria phenotype on MOX plates (black colonies with esculin hydrolysis) the following tests were performed for species identification: Gram stain; catalase reaction; presence of $\beta$ haemolysis halo production on Tripticase Soy Agar $\left(\mathrm{Oxoid}^{\circledR}\right)$ supplemented with sheep blood (5\%); CAMP tests with control strains of Staphylococcus aureus and Rhodococcus equi, and production of acid from D-glucose, L-rhamnose, mannitol and D-xylose were done.

PCR and PFGE assays. Through multiplex PCR were determined the main profiles serotypes of $L$. monocytogenes (1/2a, 1/2b, 1/2c and 4b) according to Doumith et al. (2004). Also, PCR was done to detect the presence of inlA gene in all isolates phenotypically identified as Listeria (Liu et al. 2007). PFGE was performed according to CDC procedure (PulseNet
2017) using only AscI restriction enzyme. This procedure was applied only to isolates of L. monocytogenes. Obtained patterns were analysed using BioNumerics software version 6.1(AppliedMaths ${ }^{\circledR}$ ). The Dice correlation coefficient was used to determine the similarity levels. For the cluster patterns analysis the UPGMA (unweighted-pair group matching algorithm) was used with a tolerance and optimization of $1.5 \%$. Strains that showed $\geq 80 \%$ similarity were considered as belonging to the same pulsogroup and those who shared $\geq 95 \%$ similarity were located in the same pulsotype.

\section{RESULTS}

Of the ten dairy farms visited, strains of the genus Listeria were isolated from eight and L. monocytogenes in three of them. In a farm identified as " $\mathrm{B}$ " L. monocytogenes were detected in a pool of milking cow feces and in alfalfa (Medicago sativa) pasture where cows grazed (Table 1 and 2). This was the only isolate of this species in feedstuffs. About feedstuffs samples remaining, 13 were positive for L. innocua (33\%) including concentrates, silage, hay and pasture consumed by milking cows (Table 2). On other two dairy farms identified as "D" and "F" were detected milking cows that shed L. monocytogenes in feces. No Listeria spp. was recovered from any sample of drinking water or bulk tank milk. In seven samples of ten, the soil from the entry and exit pens of the milking parlour was positive for L. innocua (Table 1 ).

All isolates phenotypically identified as Listeria monocytogenes (4) carried the encoding gene for InlA, confirming that belong to the species. On the other hand, none of the isolates identified as L. innocua showed positive PCR results for inlA. Three isolates of $L$. monocytogenes belonged to the serotype profile $1 / 2 \mathrm{a}$ and one to $4 \mathrm{~b}$ (Table 3 ). The two isolates obtained in farm B (pool of faeces and alfalfa pasture) were serotype 1/2a and showed $100 \%$ similarity in AscI-PFGE, were therefore classified as identical (Fig.1). The isolate 1/2a recovered from a faecal pool of dairy farm F showed $64 \%$ of similarity, belonging to another pulsogroup. The isolate profile $4 \mathrm{~b}$ obtained in a pool of cow faeces from farm D constituted a different pulsogroup (Fig.1).

Table 2. Quantity and percentage of isolates of Listeria spp. in feedstuffs collected during visits of dairy farms

\begin{tabular}{lcccc}
\hline \multicolumn{1}{c}{ Feedstuffs } & Samples cultured & L. innocua & L. monocytogenes & Negative \\
\hline Pasture & 15 & $1(6.7 \%)$ & $1(6.7 \%)$ & 0 \\
Concentrate & 13 & $8(61.5 \%)$ & 0 & $5(38.5 \%)$ \\
Silage & 10 & $3(30 \%)$ & 0 & $7(70 \%)$ \\
Hay & 1 & $1(100 \%)$ & 1 & 0 \\
TOTAL & 39 & 13 & 25
\end{tabular}
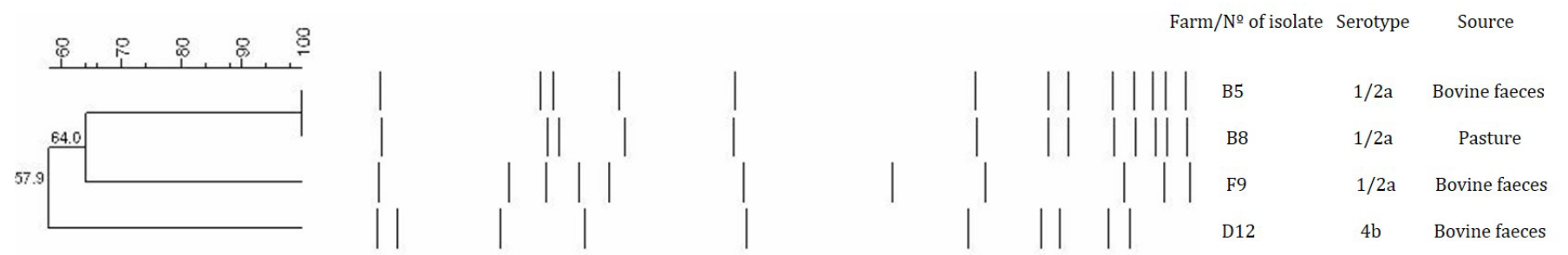

Fig.1. Dendogram of Listeria monocytogenes isolates, obtained in the Pulsed-field gel electrophoresis (PFGE) digested with AscI. 
Table 3. Multiplex PCR results for serotype in isolates of Listeria monocytogenes

\begin{tabular}{ccc}
\hline Dairy farm & Source & Serotype \\
\hline B & Pasture (alfalfa) & $1 / 2 \mathrm{a}$ \\
B & Milking cow feces & $1 / 2 \mathrm{a}$ \\
D & Milking cow feces & $4 \mathrm{~b}$ \\
F & Milking cow feces & $1 / 2 \mathrm{a}$
\end{tabular}

\section{DISCUSSION}

On three out of ten (3/10) dairy farms sampled in Paysandú, Uruguay, L. monocytogenes was detected in cattle and environment. There were identified clinically healthy dairy cows that shed L. monocytogenes via faeces, a situation previously described in studies done at dairy farms of other countries (Nightingale et al. 2004, Latorre et al. 2009, Mohammed et al. 2009b). L. monocytogenes was detected in an alfalfa pasture sample; these pastures were no fertilized with manure or effluents, therefore the faecal excretion of L. monocytogenes by cattle was likely the source of contamination (Ivanek et al. 2006). In that sense, the pulsotypes seen in the $1 / 2$ a isolates from healthy cows faeces and feed were genetically identical by AscI-PFGE. Recently, a local case of listeriosis affecting nervous system was reported on a dairy farm, where the source of infection was likely the pasture (Matto et al. 2017). In the same way, Mohammed et al. (2009a) reported a prevalence of $5.3 \%$ of $L$. monocytogenes in grass on beef cattle operations. These findings suggest that the presence of the disease should not be ruled out in cases with compatible clinical symptoms, even with no history of silage consumption. On the other hand, the presence of $L$. innocua in several of the feedstuffs analysed (pasture, silage, concentrates) indicates that these foods had conditions for the growth of L. monocytogenes (Ryser et al. 1997, Ivanek et al. 2006).

In two other farms were detected milking cows shedding L. monocytogenes, however, the source of contamination with this bacterium could not be determined. This may be explained by the low proportion of cattle that excrete L. monocytogenes via faeces in the absence of risk factors such as stress or consumption of contaminated feed (Ho et al. 2007, Ivanek et al. 2007). Notably, of the 58 pools of bovine faeces analysed, $51.8 \%$ was positive for L. innocua. This figure is relevant because cases of listeriosis caused by this bacterium have been reported in ruminants and humans (Rocha et al. 2013, Fontana et al. 2014).

Listeria spp. was not isolated from any of the bulk tank milk samples. This result could be due to different reasons: first, the protocol used had only one enrichment step that could limit bacterial growth in the culture; second, this finding might suggest that hygienic milking routines avoided contamination with faeces, and also, the adequate cleaning of the milking machine and bulk tank may have prevented the formation of biofilms containing Listeria (Yoshida et al. 1998, Latorre et al. 2009, Latorre et al. 2010); third, reports about $L$. monocytogenes prevalence in bulk tank milk is low (6.5\%) (Van Kessel et al. 2004). However, Latorre et al. (2009) suggests that repeated sampling over time of bulk tank milk is a more reliable method to estimate the presence of L. monocytogenes.
No Listeria spp. was isolated from the drinking water This finding could be because the water was not contaminated with cow faeces, like was reported in other studies in dairy farms (Latorre et al. 2009, Mohammed et al. 2009b). In this study, water samples were collected from troughs near to the milking parlour with less likelihood of faecal contamination but, many reports described isolation of L. monocytogenes or L. ivanovii in streams, lakes or ponds, being possible sources of infection to cattle and humans (Lyautey et al. 2007b; Mohammed et al. 2009a, Linke et al. 2014).

The recovery of $L$. innocua in seven samples of soil from the entry and exit pens of the milking parlour is associated with the presence of cow faeces as well as environmental conditions that allow Listeria spp. growth, such as humidity, temperature, $\mathrm{pH}$ and soil composition (mixture of humus and sand) (Latorre et al. 2009, McLaughlin et al. 2011, Linke et al. 2014). No differences were observed between L. monocytogenes and L. innocua in their capacity for survival in the soil (McLaughlin et al. 2011). Therefore, there are environmental conditions that enable survival and multiplication of $L$. monocytogenes in milking parlour soil.

The serotypes of L. monocytogenes isolated ( $1 / 2 \mathrm{a}$ and $4 \mathrm{~b})$ belong to the most frequently reported in animals and human disease (Okwumabua et al. 2005, Oevermann et al. 2010, Cartwright et al. 2013). In our country, severe human cases of listeriosis have been attributed to serotypes $1 / 2 \mathrm{a}$, $1 / 2 b$ and $4 b$ (Braga et al. 2017).Two of these isolates of L. monocytogenes $1 / 2$ a were recovered from clinically healthy animals and the remaining from a pasture. Nightingale et al. (2004) and Borucki et al. (2005) observed a higher prevalence of this serotype in clinically healthy ruminants. This serotype is commonly observed in nature, feeds and associated environments (Orsi et al. 2011, Linke et al. 2014). Orsi et al. (2011) suggest that the higher genetic variation seen in $1 / 2 \mathrm{a}$ isolates is consistent with a better adaptation to more diverse environments. L. monocytogenes serotype $4 \mathrm{~b}$ was also isolated from faeces from clinically healthy cows. This serotype is frequent in cases of listeriosis in humans worldwide, tends to produce severe disease, and is associated with the nervous form of listeriosis in ruminants (Vázquez-Boland et al. 2001, Okwumabua et al. 2005). These results suggest the potential role that these healthy animals and their sub-products would play as a source of infection from humans and/or others animals that have risk factors for severe disease. More detailed studies that include genetic comparison of human and animal isolates are required in order to clearly establish this link.

Two pulsotypes (similarity $\leq 90 \%$ ) were identified in three contemporary isolates belonging to the $1 / 2$ a PCR profile, according to the obtained results by AscI-PFGE. Despite this study included few isolates, these results agrees with previous reports that shown a high genetic diversity of L. monocytogenes in farms (Nightingale et al. 2004, Borucki et al. 2005). Genetic variability of $L$. monocytogenes among herds has also been observed and attributed to strain genetic diversity present in the gastrointestinal tract of cattle (Nightingale et al. 2004, Borucki et al. 2005, Esteban et al. 2009). More detailed epidemiological and bacteriological local studies are required to confirm or rule out this trend. 


\section{CONCLUSIONS}

Listeria spp. and specially L. monocytogenes are present in healthy milking cows as well as in environment of pasture based dairy farms of Paysandú, Uruguay. The presence of L. monocytogenes in farms poses a potential risk of milk contamination and spread of the pathogen into environment.

Listeria monocytogenes was also isolated from a pasture sample. This finding is relevant as dairy cattle diet in Uruguay is based mainly on pasture. On the other hand, the presence of $L$. innocua in other feeds analyzed such as silage or concentrate suggest that these feeds have adequate conditions for L. monocytogenes growth.

Serotypes of L. monocytogenes obtained in this study correspond to the most reported worldwide, are potentially pathogenic and associated with animal and human diseases.

Conflict of interest statement.- The authors have no competing interests.

\section{REFERENCES}

Borucki M.K., Gay C.C., Reynolds J., McElwain K.L., Kim S.H., Call D.R. \& Knowles D.P. 2005. Genetic diversity of Listeria monocytogenes strains from a highprevalence dairy farm. Appl. Environ. Microbiol. 71(10):5893-5899. <http:// dx.doi.org/10.1128/AEM.71.10.5893-5899.2005> <PMid:16204502>

Braga V., Vázquez S., Vico V., Pastorino V., Mota M.I., Legnani M., Schelotto F., Lancibidad G. \& Varela G. 2017. Prevalence and serotype distribution of Listeria monocytogenes isolated from foods in Montevideo-Uruguay. Braz. J. Microbiol. 48(4):689-694. <http://dx.doi.org/10.1016/j.bjm.2017.01.010> <PMid:28629969>

Cartwright E.J., Jackson K.A., Johnson S.D., Graves L.M., Silk B.J. \& Mahon B.E. 2013. Listeriosis outbreaks and associated food vehicles, United States, 1998-2008. Emerg. Infect. Dis. 19(1):1-9, quiz 184.<http://dx.doi. org/10.3201/eid1901.120393> <PMid:23260661>

Doumith M., Buchrieser C., Glaser P., Jacquet C. \& Martin P. 2004. Differentiation of the major Listeria monocytogenes serovars by multiplex PCR. J. Clin. Microbiol. 42(8):3819-3822.<http://dx.doi.org/10.1128/JCM.42.8.38193822.2004> <PMid:15297538>

Esteban J.I., Oporto B., Aduriz G., Juste R.A. \& Hurtado A. 2009. Faecal shedding and strain diversity of Listeria monocytogenes in healthy ruminants and swine in Northern Spain. BMC Vet. Res. 5(1):2. <http:// dx.doi.org/10.1186/1746-6148-5-2> <PMid:19133125>

Fairley R.A. \& Colson M. 2013. Enteric listeriosis in a 10-month-old calf. N.Z. Vet. J. 61(6):376-378. <http://dx.doi.org/10.1080/00480169.2013.8096 34> <PMid:23844667>

Fairley R.A., Pesavento P.A. \& Clark R.G. 2012. Listeria monocytogenes infection of the alimentary tract (Enteric listeriosis) of sheep in New Zealand. J. Comp. Pathol. 146(4):308-313. <http://dx.doi.org/10.1016/j. jcpa.2011.08.004> <PMid:21925677>

Fontana C., Sarmati L., Sancesario G. \& Favaro M. 2014. First case of Listeria innocua meningitis in a patient on steroids and eternecept. JMM Case Rep. 1(2). <http://dx.doi.org/10.1099/jmmcr.0.003103>

FSIS 2017. Isolation and identification of Listeria monocytogenes from red meat, poultry, ready-to-eat Siluriformes (fish) and egg products and environmental samples. USDA, Washington. Available at <https: //www.fsis. usda.gov/wps/wcm/connect/1710bee8-76b9-4e6c-92fc-fdc290dbfa92/ MLG-8.pdf?MOD=AJPERES> Access on Aug. 2, 2017.

Ho A.J., Ivanek R., Gröhn Y.T., Nightingale K.K. \& Wiedmann M. 2007. Listeria monocytogenes fecal shedding in dairy cattle shows high levels of day-to-day variation and includes outbreaks and sporadic cases of shedding of specific L monocytogenes subtypes. Prev. Vet. Med. 80(4):287-305. <http://dx.doi. org/10.1016/j.prevetmed.2007.03.005><PMid:17481754>
INALE 2017. Uruguay lechero. Instituto Nacional de la Leche, Montevideo. Available at <http://www.inale.org/innovaportal/v/3204/4/innova.front/ uruguay-lechero.html> Access on Jul. 13, 2017.

Ivanek R., Gröhn Y.T. \& Wiedmann M. 2006. Listeria monocytogenes in multiple habitats and host populations: review of available data for mathematical modeling. Foodborne Path. Dis. 3(4):319-336. <http://dx.doi.org/10.1089/ fpd.2006.3.319><PMid:17199514>

Ivanek R., Gröhn Y.T., Jui-Jung Ho A. \& Wiedmann M. 2007. Markov chain approach to analyze the dynamics of pathogen fecal shedding-Example of Listeria monocytogenes shedding in a herd of dairy cattle. J. Theor. Biol. 245(1):44-58. <http://dx.doi.org/10.1016/j.jtbi.2006.09.031> <PMid:17092523>

Latorre A.A., Van Kessel J.A.S., Karns J.S., Zurakowski M.J., Pradhan A.K., Zadoks R.N., Boor K.J. \& Schukken Y.H. 2009. Molecular ecology of Listeria monocytogenes: evidence for a reservoir in milking equipment on a dairy farm. Appl. Environ. Microbiol. 75(5):1315-1323. <http://dx.doi. org/10.1128/AEM.01826-08> <PMid:19114514>

Latorre A.A., Van Kessel J.S., Karns J.S., Zurakowski M.J., Pradhan A.K., Boor K.J., Jayarao B.M., Houser B.A., Daugherty C.S. \& Schukken Y.H. 2010. Biofilm in milking equipment on a dairy farm as a potential source of bulk tank milk contamination with Listeria monocytogenes. J. Dairy Sci. 93(6):27922802. <http://dx.doi.org/10.3168/jds.2009-2717><PMid:20494189>

León E.A. \& Duffy S.J. 2009. ProMESA 1.3: Programa de Muestreo Estadístico en Sanidad Animal. Unidad de Epidemiología, CICVyA, INTA, Argentina.

Linke K., Rückerl I., Brugger K., Karpiskova R., Walland J., Muri-Klinger S., Tichy A., Wagner M. \& Stessl B. 2014. Reservoirs of Listeria species in three environmental ecosystems. Appl. Environ. Microbiol. 80(18):5583-5592. <http://dx.doi.org/10.1128/AEM.01018-14> <PMid:25002422>

Liu D., Lawrence M.L., Austin F.W. \& Ainsworth A.J. 2007. A multiplex PCR for species and virulence-specific determination of Listeria monocytogenes. J. Microbiol. Methods 71(2):133-140. <http://dx.doi.org/10.1016/j. mimet.2007.08.007> <PMid:17884210>

Low J.C. \& Donachie W. 1997. A review of Listeria monocytogenes and Listeriosis. Vet. J. 153(1):9-29. <http://dx.doi.org/10.1016/S1090-0233(97)800056> <PMid:9125353>

Lyautey E., Hartmann A., Pagotto F., Tyler K., Lapen D.R., Wilkes G., Piveteau P., Rieu A., Robertson W.J., Medeiros D.T., Edge T.A., Gannon V.\& Topp E. 2007a. Characteristics and frecuency of detection of fecal Listeria monocytogenes shed by livestock, wildlife, and humans. Can. J. Microbiol. 53(10):1158-1167. <http://dx.doi.org/10.1139/W07-084> <PMid:18026208>

Lyautey E., Lapen D.R., Wilkes G., McCleary K., Pagotto F., Tyler K., Hartmann A., Piveteau P., Rieu A., Robertson W.J., Medeiros D.T., Edge T.A., Gannon V. \& Topp E. 2007b. Distribution and characteristics of Listeria monocytogenes isolates from surface waters of the south nation river watershed, Ontario, Canada. Appl. Environ. Microbiol. 73(17):5401-5410. <http://dx.doi. org/10.1128/AEM.00354-07><PMid:17630309>

Matto C., Varela G., Mota M.I., Gianneechini R. \& Rivero R. 2017. Rhombencephalitis caused by Listeria monocytogenes in a pastured bull. J. Vet. Diagn. Invest. 29(2):228-231. <http://dx.doi.org/10.1177/1040638716689116> <PMid:28166691>

McLaughlin H.P., Casey P.G., Cotter J., Gahan C.G.M. \& Hill C. 2011. Factors affecting survival of Listeria monocytogenes and Listeria innocua in soil samples. Archs Microbiol. 193(11):775-785. <http://dx.doi.org/10.1007/ s00203-011-0716-7> <PMid:21611773>

Mohammed H.O., Atwill E., Dunbar L., Ward T., McDonough P., Gonzalez R. \& Stipetic K. 2009a. The risk of Listeria monocytogenes infection in beef cattle operations. J. Appl. Microbiol. 108(1):349-356. <http://dx.doi. org/10.1111/j.1365-2672.2009.04446.x> <PMid:19664067>

Mohammed H.O., Stipetic K., McDonough P.L., Gonzalez R.N., Nydam D.V. \& Atwill E.R. 2009b. Identification of potential on-farm sources of Listeria monocytogenes in herds of dairy cattle. Am. J. Vet. Res. 70(3):383-388. <http://dx.doi.org/10.2460/ajvr.70.3.383> <PMid:19254151> 
Nightingale K.K., Fortes E.D., Ho A.J., Schukken Y.H., Gröhn Y.T. \& Wiedmann M. 2005. Evaluation of farm management practices as risk factors for clinical listeriosis and fecal shedding of Listeria monocytogenes in ruminants. J. Am. Vet. Med. Assoc. 227(11):1808-1814. <http://dx.doi.org/10.2460/ javma.2005.227.1808> <PMid:16350271>

Nightingale K.K., Schukken Y.H., Nightingale C.R., Fortes E.D., Ho A.J., Her Z., Gröhn Y.T., McDonough P.L. \& Wiedmann M. 2004. Ecology and transmission of Listeria monocytogenes infecting ruminants and in the farm environment. Appl. Environ. Microbiol. 70(8):4458-4467. <http://dx.doi.org/10.1128/ AEM.70.8.4458-4467.2004><PMid:15294773>

Oevermann A., Zurbriggen A. \& Vandevelde M. 2010. Rhombencephalitis caused by Listeria monocytogenes in humans and ruminants: a zoonosis on the rise? Int. Persp. Infect. Dis. 2010: 632513. <http://dx.doi. org/10.1155/2010/632513>

Okwumabua O., O'Connor M., Shull E., Strelow K., Hamacher M., Kurzynski T. \& Warshauer D. 2005. Characterization of Listeria monocytogenes isolates from food animal clinical cases: PFGE pattern similarity to strains from human listeriosis cases. FEMS Microbiol. Letters 249(2):275-281. <http:// dx.doi.org/10.1016/j.femsle.2005.06.018> <PMid:16000241>

Orsi R.H. \& Wiedmann M. 2016. Characteristics and distribution of Listeria spp., including Listeria species newly described since 2009. Appl. Microbiol. Biotechnol. 100(12):5273-5287. <http://dx.doi.org/10.1007/s00253016-7552-2><PMid:27129530>

Orsi R.H., Bakker H.C. \& Wiedmann M. 2011. Listeria monocytogenes lineages: genomics, evolution, ecology, and phenotypic characteristics. Int. J. Med.
Microbiol. 301(2):79-96. <http://dx.doi.org/10.1016/j.ijmm.2010.05.002> <PMid:20708964>

PulseNet 2017. Standard operating procedure for PFGE of Listeria monocytogenes. Center for Disease Control and Prevention, Atlanta. Available at <https:// www.cdc.gov/pulsenet/pdf/listeria-pfge-protocol-508c.pdf> Access on Aug. 2, 2017.

Rocha P.R.D., Dalmasso A., Grattarola C., Casalone C., Del Piero F., Bottero M.T. \& Capucchio M.T. 2013. Atypical cerebral listeriosis associated with Listeria innocua in a beef bull. Res. Vet. Sci. 94(1):111-114. <http://dx.doi. org/10.1016/j.rvsc.2012.07.017><PMid:22898534>

Ryser E.T., Arimi S.M. \& Donnelly C.W. 1997. Effects of pH on distribution of Listeria ribotypes in corn, hay and grass silage. Appl. Environ. Microbiol. 63(9):3695-3697. <PMid:9293020>

Van Kessel J.S., Karns J.S., Gorski L., McCluskey B.J. \& Perdue M.L. 2004. Prevalence of Salmonellae, Listeria monocytogenes, and fecal coliforms in bulk tank milk of US dairies. J. Dairy Sci. 87(9):2822-2830. <http:// dx.doi.org/10.3168/jds.S0022-0302(04)73410-4><PMid:15375040>

Vázquez-Boland J.A., Kuhn M., Berche P., Chakraborty T., Domínguez-Bernal G., Goebel W., González-Zorn B., Wehland J. \& Kreft J. 2001. Listeria pathogenesis and molecular virulence determinants. Clin. Microbiol. Rev. 14(3):584-640. <http://dx.doi.org/10.1128/CMR.14.3.584-640.2001><PMid:11432815>

Yoshida T., Kato Y., Sato M. \& Hirai K. 1998. Sources and routes of contamination of raw milk with Listeria monocytogenes and its control. J. Vet. Med. Sci. 60(10):1165-1168. <http://dx.doi.org/10.1292/jvms.60.1165> $<$ PMid:9819776> 